Palestine Exploration Quarterly

\title{
Researches on the Pathogenic Microbes of the Mud of the Dead Sea
}

\section{L. Lortet}

To cite this article: M. L. Lortet (1892) Researches on the Pathogenic Microbes of the Mud of the Dead Sea, Palestine Exploration Quarterly, 24:1, 48-50, DOI: 10.1179/peq.1892.24.1.48

To link to this article: http://dx.doi.org/10.1179/peq.1892.24.1.48

巴nublished online: 20 Nov 2013.

Submit your article to this journal $\longleftarrow$

Џll Article views: 3

Q View related articles $\sqsubset$

Citing articles: 3 View citing articles 5 


\title{
RESEARCHES ON THE PATHOGENIC MICROBES OF THE MUD OF THE DEAD SEA.
}

\author{
By M. L. LoRTet.
}

(Translation.)

"IN a former communication I have shown that the deposits of the filtering galleries, as well as the deep mud, of the Lake of Geneva, may preserve alive the adult forms or the spores of a certain number of pathogenic microbes. It is interesting to know whether the same results can be established in sheets of water subject to entirely different conditions of temperature, light, and, above all, of chemical composition, and it is with a view to the solution of this problem that I have analysed the mud which has been sent to me from the Dead Sea by M. Barrois, Professor of the Faculty of Medicine at Lille.

"The Dead Sea, placed at the southern end of the Valley of the Jordan, presents about the same extent as the Lake of Geneva. It occupies a vast basin, which is certainly the deepest depression on the face of the earth, for its surface is 400 metres below that of the Mediterranean. Rocky walls, rising to 800 metres, surround it on every side. This sea is nourished by the Jordan, a rapid river, whose waters are, during a part of the year, charged with mud and organic matters proceeding from its source amid the snows of Mount Hermon. The saline, thermal, and bituminous springs contribute around its margin a considerable mass of water, which may double that brought by the Jordan.

"The density of the water of the Dead Sea is 1,162, whilst that of the ocean is only 1,027 ; so that the human body, as has been frequently said, and as I have myself been able to ascertain in two successive visits, floats easily, and without the help of any movement, on the surface of this heavy liquid.

"The waters of the Dead Sea cannot escape by any known issue, and as it is very evident that its level has subsided considerably, the evaporation must raise every day at least 6,500,000 tons of water, an enormous mass, which is, however, easily drawn up by the rays of a fiery sun, the Valley of the Dead Sea being one of the hottest points on the globe. During a long series of centuries the waters must have been concentrating more and more, and the inferior beds of this liquid mass are formed only of mud enclosing an enormous quantity of crystalline needles of different salts forming a semi-fluid pap.

"It is this-strange medium, so strongly charged with saline substances injurious to the higher organisms, that I have been studying from a bacteriological point of view. The water drawn at 200 metres and brought home, in 1866, by M. Lartet, the geologist attached to the expedition of the Duke de Luynes, has been analysed by M. Terreil, who found :- 


\begin{tabular}{|c|c|c|c|c|c|}
\hline Chloricle of & Sodium & .... & $\cdots$ & $\cdots$ & $60 \cdot 125 \mathrm{gr}$. \\
\hline , & Magnesium & $\ldots$ & .... & $\ldots$ & $160 \cdot 349$ \\
\hline$"$ & Potassium & $\ldots$ & $\therefore$ & .• & $9 \cdot 63$ \\
\hline & Calcium & $\ldots$ & ... & •. & $10 \cdot 153$ \\
\hline romid & Magnesium & $\ldots$ & $\ldots$ & $\ldots$ & $5: 04$ \\
\hline & Lime & $\ldots$ & $\ldots$ & $\ldots$ & $0 \cdot 78$ \\
\hline
\end{tabular}

"A total of : $246.077 \mathrm{gr}$. of saline matter per litre. In certain parts the bromine, which the experiments of Paul Bert have shown to have a very energetic action upon the vitality of the tissues, may reach even to 7 gr. per litre. The microscopist Ehrenberg, the naturalists of the expedition of Captain.Lynch, those who accompanied the Duke de Luynes, myself in 1875 and in 1880, have veritied that the waters of the Dead Sea do not contain any living vegetable or animal organism. Recently, M. Barrois, the able zoologist of the Faculty of 'Lille, has traversed in a boat a great part of the Dead Sea, hoping to find there the inferior auimalculæ. But, like his predecessors, he has been able to ascertain that these waters are entirely sterile.

"In consequence of the statements made by such competent men, I thought that the waters of the Dead.Sea might well, in consequence of their concentration and their special chemical composition, constitute an aseptic liquid capable, perhaps, of some useful application.

"The semi-liquid mud, collected with care by M. Barrois, was then diluted suitably, and distributed in many hundreds of tubes and flasks, What was not my profound astonishment to observe, after forty-eight Hours, that all the nutritive. media contained, especially in their deep parts, two micro-organisms perfectly recognisable by their altogether special form: those of gangrène gazeuse, characterised by large bacilli accompanied by corpuscles like the clapper of a bell, and those of tetanus, so easily recognisable by their form resembling a pointed nail with a spherical head.

"Guinea-pigs inoculated with sterilised water mixed with a little of the mud were all dead in less than three days of gangrenous septicemia, with all the train of symptoms, in some degree intensified, characteristic of this formidable affection. Guinea-pigs and donkeys have also all perished from the same affection after inoculation with the product of our culture in media deprived of conlact with oxygen. In the one case and in the other, numerous bacilli have always shown themselves in the peritoneum, in the muscles, and in the blood, which have transmitted the malady to other subjects, and which, cultivated afresh, have reproduced the bcdies like the clapper of a bell, which are so characteristic. The affection engendered by these organisms is the gangrène gazeuse and not the charbon symptomatique, with which one might confound it, for young oxen experimented upon have not been affected by our inoculations Most of the guinea-pigs inoculated directly with the mud presented tetanic, symptoms, corresponding to the frequency of the organisms described above. 
"The experiments here described prove, then, once for all, that certain pathogenic microbes may resist for a long period, whether in the adult state or in the form of spores, prolonged contact with large masses of water, even whilst they contain, in considerable quantities, salts injurious to every other organism, animal or vegetable. From a practical point of view, the above researches demonstrate, as far as the evidence goes, that it will be imprudent to regard water strongly charged with salt as an antiseptic liquid capable of protecting against attacks of tetanus and gangrène gazeuse."

\section{ON THE FALL OF RAIN, THE AMOUNT OF CLOUD, THE FREQUENCY OF CLOUDLESS SKIES, AS RECORDED DAILY, AT 9 A.M. LOCAL TIME, BY HERR DREHER AT SARONA IN THE TEN YEARS ENDING 1889.}

$$
\text { By James GLAisher, F.R.S. }
$$

THE receiving area of the Rain Gauge was placed near the surface of the ground, the amount of cloud was estimated by considering a cloudless sky as 0 , and an overcast sky as 10 . 